\title{
SOUNDS OF DEMOCRACY: Performance, Protest, and Political Subjectivity
}

\author{
LAURA KUNREUTHER \\ Bard College \\ (D) http://orcid.org/0000-0002-1784-8193
}

Democracy is commonly associated with various forms of voicing: political speeches, public gatherings of shouting protesters, filibusters in the halls of Congress, or heated debates in teashops, salons, and newspapers around the world. Everyday discussions about democracy tend to imply at least two different understandings of voice. First, liberal democracy is founded on the ideal that every adult citizen "has a voice" that can and should be heard, just as they have a vote, and that these voices/votes are functionally equivalent to each other. Consider, for example, a mass email from the advocacy organization People for the American Way that circulated in the lead-up to the 2016 election in the United States: "The strength of our democracy is tied to each individual voice being heard and every vote counted." Voice in this case is linked to individual selves, and particularly to selfinterest, consciousness, and desire. The expression of democratic belonging requires active participation by individuals with a multitude of different interests, individuals who jostle for a space to speak, debate, and discuss. Scholars often emphasize the use of language as central to democratic practice - via texts in the public sphere (Habermas 1989), social media (Juris 2012; Bonilla and Rosa 2015), face-to-face debates in coffee and tea houses (Cody 2011), or well-crafted oratory (Bate 2009) — and thus voice serves as a metaphor for political participation. 
A second common association of voice with democracy appears in discussions of political representation, embodied in the notion of a representative democracy in which a politician claims to represent the voices of many. Recall Donald Trump's repeated comment in his speech at the Republican National Convention in 2016, "I am your voice," which suggested that his role would be to represent the numerous voters who, as Trump put it, "no longer have a voice." Once votes are cast by the ostensibly voiceless, they are said to gain a voice through its explicit mediation by an elected official.

Political metaphors of voice are often disembodied, rarely invoked with reference to the materiality or texture of embodied voices or other actual sounds that make up democratic practice. ${ }^{1}$ In many philosophical discussions of democracy, metaphors of political voice almost always refer to discursive speech, analytic or reasoned discourse. They rarely conjure other forms for political utterance, sound, or even noise - voices shouting, collective chanting, the production of noise for political effect, or, significantly, the active performance of silence - that make up the many practices of participatory democracy. In such collective performances, the notion of voice depends not on a single speaker but on a mass collectivity to make any message heard. This notion of voice is popularly embodied in the "human mic" or "people's mic" used during recent U.S. protests, when a single person's speech or chant is spoken in short segments and then repeated by the crowd, so that the words can be heard far from the source. The human mic works through the nonmechanical amplification of voice, through collective resounding, and in so doing it ironically inverts familiar modes of electronic mediation associated with modernity and mass experience (Kelp-Stebbins and Schifani 2015). The human mic emphasizes a collective voice that, as Homay King (2012, 239) notes, "shifts away from sovereign, solitary personhood." By "extending the communality of the movement through embodiment," the human mic enacts the very thing that it seeks to represent or demand (Kelp-Stebbins and Schifani 2015). Writes King (2012, 239): “This is what democracy looks like." Or we might say, this is what democracy sounds like.

While the global discourse of voice (in English) rarely turns our attention to the soundings of democracy, the term āwāj- used in many South Asian languages - refers explicitly to sound and to metaphoric meanings of voice. My first encounters with $\bar{a} w a \bar{j}$ came initially through my research in Kathmandu, where I spent a lot of time analyzing FM radio programs and fan letters in which listeners frequently commented on the sonic qualities of a radio host's voice, described as either swar (voice of an individual person or animal) or $\bar{a} w a \bar{j}$ (noise, sound, voice). ${ }^{2}$ 
Most Nepalis would translate the word $\bar{a} w a \bar{j}$ as "sound" or, if they are consumers of media or activists in the political sphere, as “voice.” Ralph Turner's $(1931,26)$ Nepali-English dictionary gives us three possible translations: "noise, sound, voice."

At a metaphorical level, āwāj resonates with modern, global discourses of voice used to describe interior thoughts and desires, political consciousness, agency, and modes of selfhood central to modern publics and democratic practice (Keane 1999; Kunreuther 2014; Weidman 2014; Fisher 2016), as in phrases like mahilāko āwāj (women's voice) or janājātiko āwāj (ethnic nationalist voice) or āwāj uthāune (raising voice). Yet $\bar{a} w \bar{a} j$ also includes reference to a wide array of phenomena that are not human or discursive at all: natural and mechanical sounds or noises. ${ }^{3}$ The term $\bar{a} w \bar{a} j$, then, quite literally, brings together what Amanda Weidman (2014) and others have identified as two registers of voice: first, the study of vocal sound, and second, its life as a discursive category related to discussions of power, subjectivity, representation, and agency. Because sound affects us in ways that often exceed words, āwāj helps us focus our attention on the connections between the rational and the affective, the articulate and the inarticulate, rather than their fundamental division, raising questions around how we think about democratic practice.

$\bar{A}_{w a} j$ also offers us a way to break open the ubiquitous discourse of voice used in global human-rights organizations, humanitarian discourse, and liberal understandings of the public sphere. In these contexts, we often find a group or a person who is presented as voiceless but who might be able to "gain a voice" through some effort, often with the help of another organization, medium, authority, or knowledge producer. While $\bar{a} w a \bar{j}$ and $\bar{a} w a \bar{j}$ uthāune echo these global ideas about voice, I do not believe that there is an equivalent subject - a voiceless subject - implied in the concept of $\bar{a} w a \bar{j}$. This may be related to the broader nexus of sounds embraced by the term.

In the present article, I follow the pathways laid out by the concept of $\bar{a} w \bar{a} j$ by considering two examples of participatory democracy on the streets of Kathmandu. Ashmina Ranjit's performance art piece, A Happening/An Installation: Nepal's Present Situation, 2004, intended to dramatize the nation's suffering in the midst of the Maoist People's War and, as Ashmina explained to me, to "wake the people of Kathmandu up.”4 Eight years later, activists staged a political demonstration lasting 107 days in front of the prime minister's home, which was called Occupy Baluwatar or Baluwatar Satyagraha, in protest of a young returning migrant being robbed by an immigration official and then raped by a Nepali police- 
man. Despite its initial name, Occupy Baluwatar was quite unlike the Occupy movements around the globe: it did not target global capital, and the activists had a specific aim to further a concrete legal action (cf. Juris and Rasza 2012). But in using the same name as the movement that popularized the use of the human mic and its ideals, Occupy Baluwatar created many formal similarities to other global protest movements: its reliance on social media, the use of silence and noise, as well as the occupation of public space.

Both A Happening and the Occupy Baluwatar protests involved a similar demographic of cosmopolitan young Nepalis, many of whom had traveled or studied abroad, some of whom were journalists who often wrote in English and spoke a mix of Nepali and English, and some of whom in fact participated in both events (such as Ashmina). Most of the people involved in these events see themselves as feminists, activists or, in Ashmina's case, as an "artivist," who denounce party politics even when, in the case of the Baluwatar movement, they seek to negotiate directly with the state. ${ }^{5}$ They practice what Heather Hindman (2014) has called "DIY" democracy, which exhibits a "confluence between anarchic and libertarian rejections of the state.” Presenting themselves as part of nāgarik samāj (civil society), they distinguish their actions from the tactics of political society (see Chatterjee 2006), which uses violence or threats of violence to protest against the state.

Though different in intention and to some degree audience, both the performance piece and the Occupy protest moved between the physical, public space of the street and the mediated public sphere of circulating texts and voices; both used sound strategically. Drawing on local and global strategies of protest, participants described both events as examples of $\bar{a} w a \bar{j} j$ uthāune. As forms of $\bar{a} w a \bar{j}$, they invite us to consider sound, noise, and voice "as intertwined and diverging trajectories, rather than a unified progression to an autonomous, speaking subject" (Manoukian 2010, 241). They indicate a range of performances that cultivate democratic and political subjectivity in Nepal. ${ }^{6}$

In following $\bar{a} w \bar{a} j$, I am not seeking to indigenize a global concept like voice. Instead, I argue that $\bar{a} w \bar{a} j$ and $\bar{a} w a \bar{j}$ uthāune offer another global trajectory of voice - one that might provincialize Northern discourses of voice. In Provincializing Europe, Dipesh Chakrabarty (2000) suggests that the concepts we use to understand political modernity such as citizenship, state, the individual, the subject, the public sphere, human rights, and so on are both indispensable and inadequate because their assumptions about universal humanity always take Europe as its subject. The concept of $\bar{a} w a \bar{j}$ does the work of provincializing that Chak- 
rabarty argues for insofar as it offers new ways of thinking about the political role of sound that comes out of a South Asian concept but is equally at work in EuroAmerican contexts.

$\bar{A} w a \bar{a} j$ is a global discourse in its own right. Often associated with radical politics, $\bar{a} w \bar{a} j$ is also a common name for newspapers, NGOs, and politically inspired performances throughout South Asia, as well as in Kenya, the United Kingdom, and North America, where there are large South Asian populations. Derived from the Persian avaaz (sound, voice, or song), in these contexts, the political and the sonic referents of $\bar{a} w a \bar{j}$ often overlap. The online activist network Avaaz (n.d.), started by a Canadian of South Asian descent, emphasizes the global nature of its campaigns by stating in the "Mission" section of its website: "Avaazmeaning 'voice' in several European, Middle Eastern, and Asian languages launched in 2007 with a single democratic mission: organize citizens of all nations to close the gap between the world we have and the world most people everywhere want." In using the term avaaz rather than voice, the organization signifies its departure from mainstream global media organizations, and its alignment with the global South.

$\bar{A}_{w a} j$ uthāune (raising voice) is sound as signal that, like Setrag Manoukian's $(2010,241)$ analysis of crowds in viral videos during protests after recent Iranian elections, "unsettles both the insatiable desire to give closure and the refusal to engage and reflect critically." By considering affective sounds of protest that circulate on the street and in the media or on the Internet, we move away from an understanding of voice as a form of transparent political representation of specific demands. W. J. T. Mitchell $(2012,10)$ describes the Occupy movements, for example, as "a demand for presence, an insistence on being heard, before any specific political demands are made; a demand that the public be allowed to gather and remain in a public space." Moreover, he wonders what "iconic figures" (Mitchell 2012, 13) emerge from such protests. To get at the way in which hearing is a central affective component of democratic practice, here I ask: What are the sonic motifs of contemporary protests?

From a broader perspective we might also ask: What does participatory democracy sound like? This question is inspired by a proliferation of critical studies that explore the affective, sensory, and embodied dimensions of political subjectivity (e.g., Athanasiou 2005, 2017; Stoler 2007; Manoukian 2010; Mazzarella 2010, 2015; Butler 2015; Cody 2015). My analysis here contributes to a growing literature on the role of sound and silence in protests and affective publics (e.g., Sterne and Davis 2012; Gray 2013; Manabe 2015; Novak 2015; Tausig 2015; 
Abe 2016; Sonevytsky 2016), and I take up Stefan Helmreich's point that “telling signal from noise is no simple matter" (Garcia Molína and Cossette 2016). Here I consider four sonic motifs: performed silence, broadcasts of recorded crying, honking, and banging on plates. ${ }^{7}$ These are neither fully discursive nor fully musical, evincing elements of both. They create "democratic soundscapes" (Kunreuther 2017) out of and against the contemporary urban sounds of Kathmandu. ${ }^{8}$ Such soundscapes are oriented toward a vast media complex - indeed, are largely produced for media that become a feature of the performances - while creating presence within the moment through silence, voices, and bodily assembly.

Audio 1. Kathmandu āwäj. This sound piece moves through several different neighborhoods of Kathmandu and Patan over the course of a fictive day, echoing the pleasures, frustrations, and humor of the dense and richly layered urban soundscape. Created and edited by Laura Kunreuther.

Urban soundscapes change radically through history and over the course of a day. ${ }^{9}$ In the early mornings in the cities of the Kathmandu Valley, ${ }^{10}$ one hears the sounds of dogs barking, birds chirping, the rumbling of early trucks, and bells ringing in homes and at corner temples for morning puja (worship). The sounds of morning traffic, the whoosh of pressure cookers letting off steam, and the shouts of children going to school begin around 9 or 10 a.m. Those who know the city well are likely able to recognize where they are by what they hear. Different parts of the city are characterized by different sounds and different languages (generally Nepali, Newari, English, and Hindi) related to specific people, practices, and histories of a neighborhood. A passerby will know that he or she is at Ratna Park bus station from the noise of buses revving up their motors, peddlers hawking fruit or tea, bus drivers yelling out their destinations. They will know they are in a specific bahal (courtyard) or section of Patan by the chinking sounds of Newar craftsmen tapping their brass sculptures of divine figures into perfect form. ${ }^{11}$ In the late-night hours, in the tourist and youthful area of Thamel, repetitive drumbeats and loud electric-guitar music seep through the closed doors of dance bars. In other parts of the city, the calls and responses of dogs barking break up the silence of night, echoing across the valley.

These typical soundscapes of Kathmandu are nominally and sometimes radically altered during the various protests that have occurred over nearly three decades, the most common being bandas (general strikes) or chakka jams (traffic 
blockades) when all traffic, commerce, schools, and other public institutions stop or are threatened into ceasing their work. ${ }^{12}$ Such methods parallel the actions of what Partha Chatterjee (2006) has called political society, though in Nepal the line between civil and political society may not be very clear (see Lakier 2014). On such days of protest, a stark difference manifests itself in the soundscape of the capital city. The streets are largely empty (except for buses marked "tourist"), and people who do go out are generally walking or on bicycles. The lack of typical daily sounds (not quite silence) makes the protests palpable - along with the threat of violence they entail - even for those who do not know what a particular banda is about. The relative quiet of a banda is punctuated at various times and places by the sound of stones being thrown at businesses that have not shut down. Overall, one hears the stunning absence of traffic.

\section{FIRST MOTIF: SILENCE}

On May 1, 2004, a procession of people dressed in black took to the streets of Kathmandu. Processions, or julusharu, were not an unusual sight at the time; they were daily happenings enacted by protesters who spoke out against the royal regime, the demise of the democratic process, and the ongoing civil war between the Maoists and the Nepali state. But this procession was not a political rally; it was a piece of performance art orchestrated by Nepal's renowned conceptual artist Ashmina Ranjit. The black-clad performers walked solemnly and silently in pairs. One person would suddenly fall to the ground, feigning death, while the other drew his or her outline on the street in chalk. Many carried handheld FM radio sets, from which the sound of crying war victims was broadcast across all FM stations and the state-owned Radio Nepal for a full hour, from 5 to 6 p.m. One performer attached a megaphone to a radio to amplify the sound. A newspaper headline about A Happening read: “Ashmina 'raises her voice' against present madness" (Pradhan 2004). Sometime after the event, Ashmina explained to me what she envisioned with the performance: "It's for peace and it's against the ongoing violence," she said. "And it's not only me — this is our voice [hāmro āwāj]." The performance produced and provided material to reflect on the media of democratic protest - ranging from radio infrastructure to collective processions.

I was initially drawn to write about Ashmina's performance after learning about her remarkable use of FM radios to broadcast the sounds of wailing. But when I first met Ashmina to talk about A Happening, a year later, she began telling me that the event was marked, at least initially, by wordlessness or silence. The sonic space it created, then, echoed the quietness of the streets during a banda. 


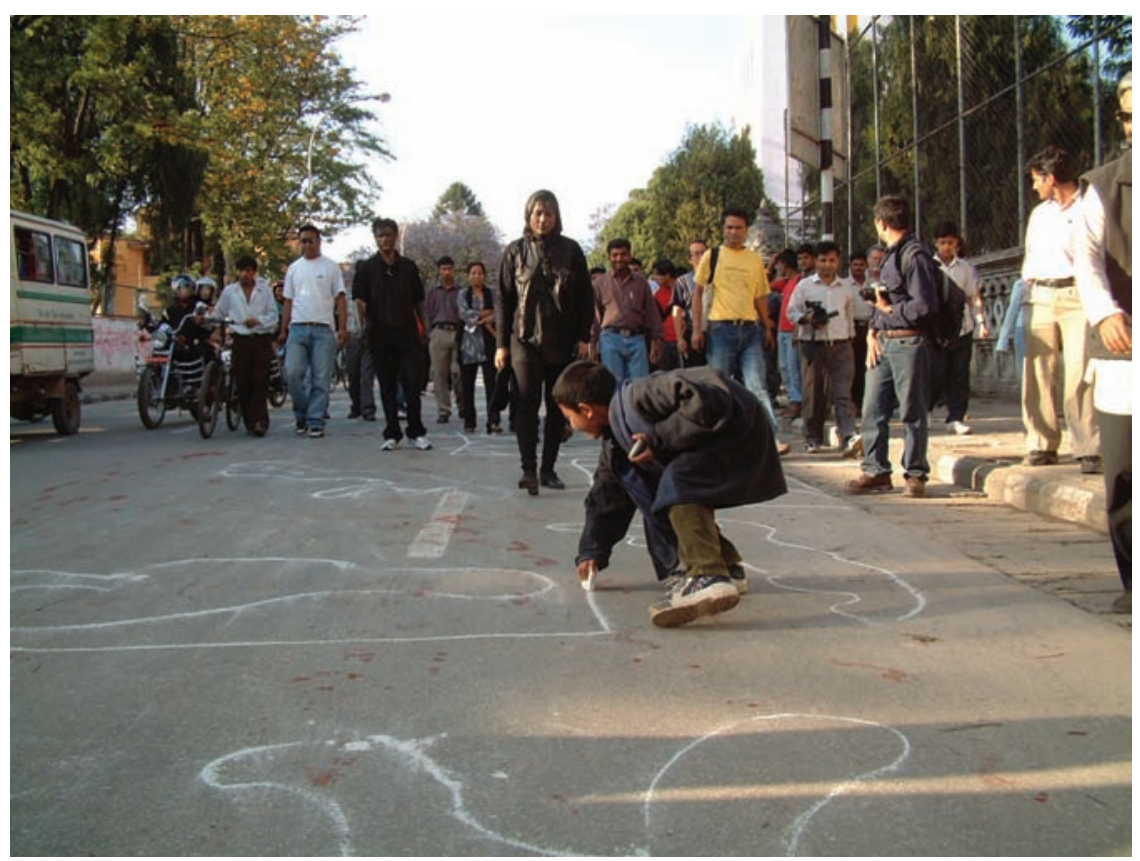

Figure 1. Ashmina Ranjit and crowd at A Happening/An Installation: Nepal's Present Situation, 2004. Photo courtesy of Ashmina Ranjit.

A Happening was staged at a volatile moment in a particularly significant place: during the height of the Maoist People's War, and a year after the king had dissolved the parliament and had appointed a prime minister without holding elections. Just days after Ashmina's performance, Prime Minister Surya Bahadur Thapa resigned due to growing pressure from political parties. The performance began directly in front of the Nepal's first educational institution, Tri-Chandra College, near the famed Democracy Wall of Ratna Park that commemorated the 1990 People's Movement, and it was the site of the most violent and regular protests at that time. This site became a key place for organizing protests from 2001 to- 2004, as activists often deliberately tried to get arrested just beside Democracy Wall (Snellinger 2010, 125). Typically, during the weeks prior to Ashmina's A Happening, one could hear protesters shouting near Democracy Wall, which ended with police rounding up activists in blue police vans. Before May 1 , Ashmina had asked political leaders and key student activists to take their protests elsewhere on that day or to join in the procession. She had also talked to police and army personnel, who typically broke up such rallies, asking that they not arrest the eighty-some students she planned to bring. Some activists transported 
their protests to New Road, a main thoroughfare; others joined the performance. All were instructed to wear black and to move without saying anything, though they were advised to moan, cry out, or occasionally cup their hands and ask for water from strangers on the street. Each participant used their voice as a medium for sound, then, not a medium for articulate expression. Ashmina had approached the households located along the route of the procession, asking them to put on their radios for a full hour, so passersby could hear her soundtrack. She placed brass bowls of water outside residents' homes, which she colored with vermilion powder.

The performance began with Ashmina and her collaborator, Sunil Pokharel, sitting silently at the central clock tower (Ghanta Ghar) and tearing books as ink dripped onto their faces from above. A painted image of the national clock tower, broken, lay in front of them on the street. "The time of the nation had come to a standstill," wrote journalist Sanjeev Uprety (2004). Some of A Happening's power came from it being staged during the 2004 governmental ban on public gatherings in certain places, including, due to its symbolic significance, in front of Democracy Wall. Ashmina marked this fact by painting a "no entry" symbol

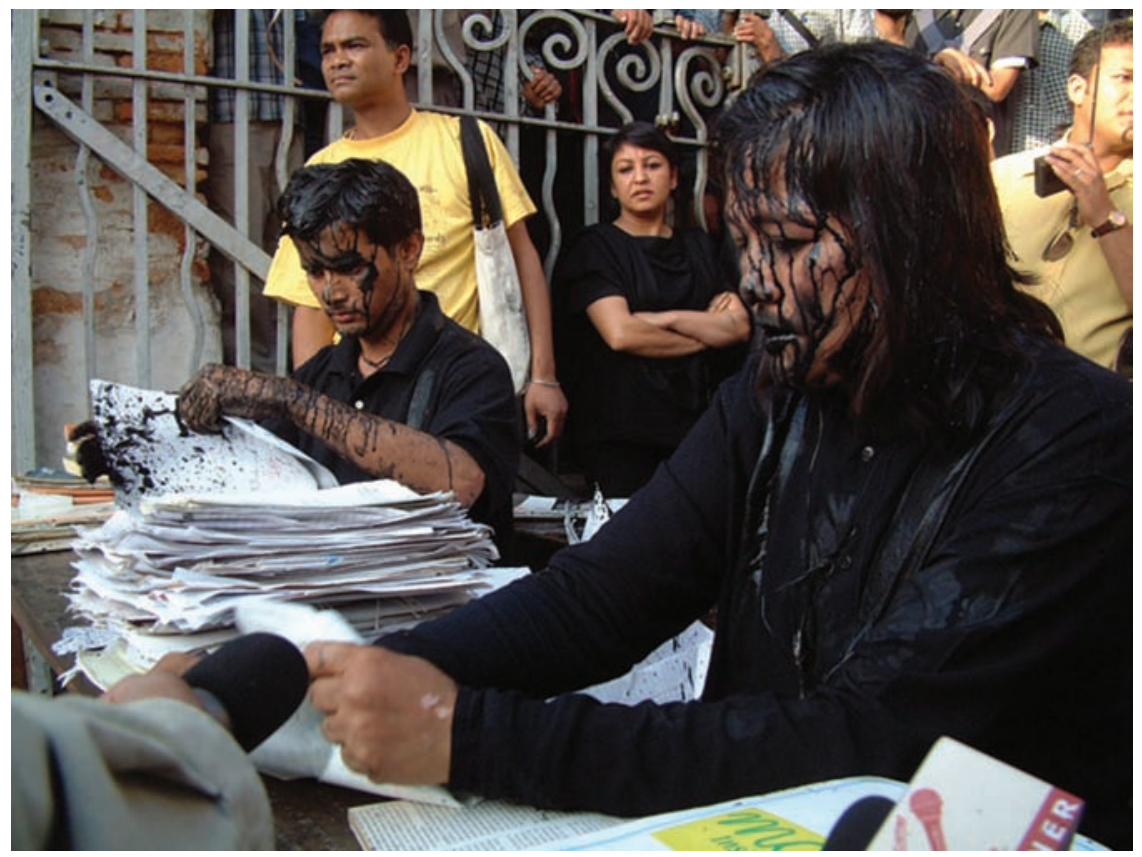

Figure 2. Ashmina Ranjit and Sunil Pokharel streaked in black ink. Photo courtesy of Ashmina Ranjit. 


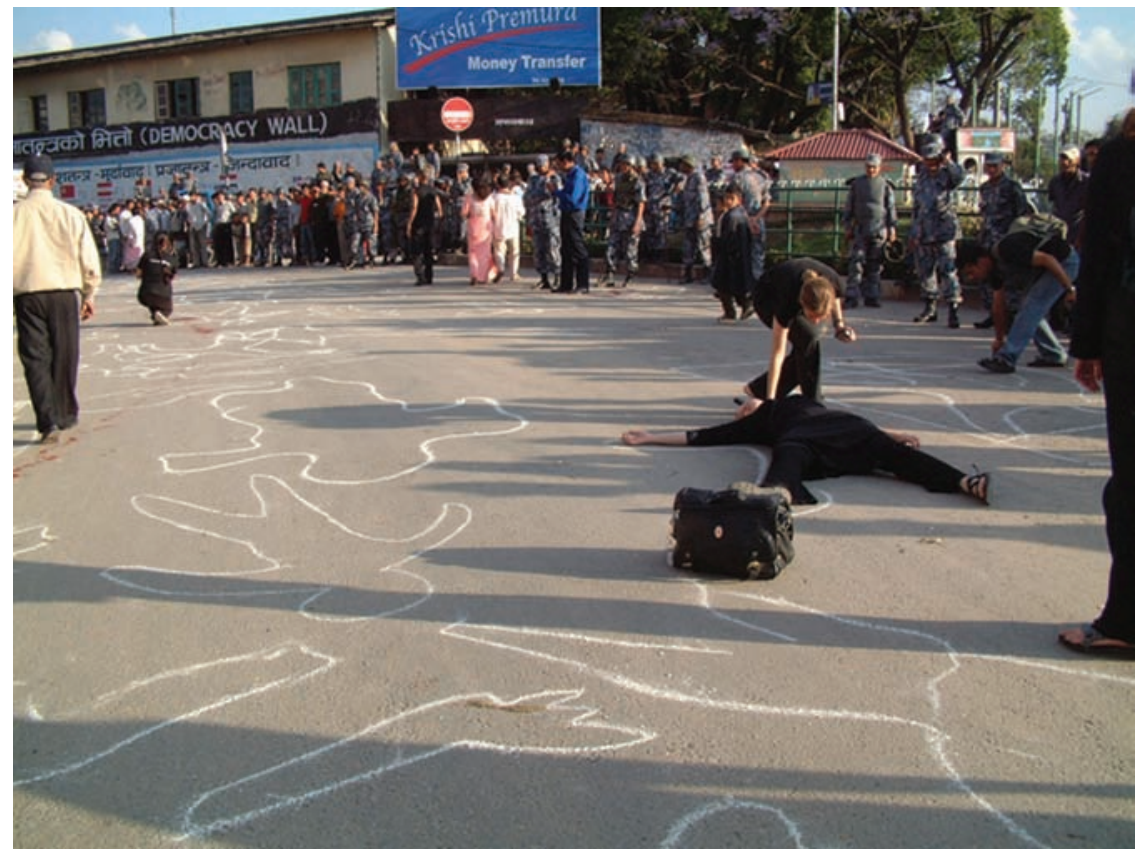

Figure 3. Chalk bodies and Democracy Wall. Photo courtesy of Ashmina Ranjit.

on the street. Contrary to other protests, this one was not interrupted by police vans and arrests. Uprety (2004) reported a police officer commenting that "if all of the political protests were this peaceful, [police] wouldn't have to fire tear gas and plastic bullets." Perhaps because $A$ Happening was understood as art that made no specific political demands, police and army personnel complied with Ashmina's request not to carry out arrests.

Ashmina's strategic use of silence and black clothing echoed prior political protests and demonstrations in Nepal. In Nepal and other parts of South Asia, black signifies protest, often silent protests that draw attention to the perceived darkness of a regime. During the teachers' strike of 1984 and 1985, for example, teachers wore black armbands and went to their classrooms but refused to speak, hoping to move their employers to action while also remaining respectful of the lines of hierarchy (Burghart 1996, 310-11). Several years later, activists in the 1990 People's Movement used tactics of provocative silence not only to rebuke the government but also to oppose and dramatize government censorship. Increasingly, journalists or activists explained their silence directly. In 1990, more than two hundred writers and artists staged a silent gathering in front of TriChandra College - in the same location where Ashmina performed A Happening - 
with black scarves tied around their faces. ${ }^{13}$ Journalists and media personnel staged a similar protest fifteen years later after the government had raided an FM radio station, dramatically representing the condition of silence they found themselves in. Even the nonauditory media of newspapers invoked a metaphorical silence. In March 1990, a blank editorial page in the weekly Nepali Āwāj (Nepali Voice) was appended with a short explanation of its emptiness: "To oppose the arrests of around forty journalists and other professionals from all over the country."

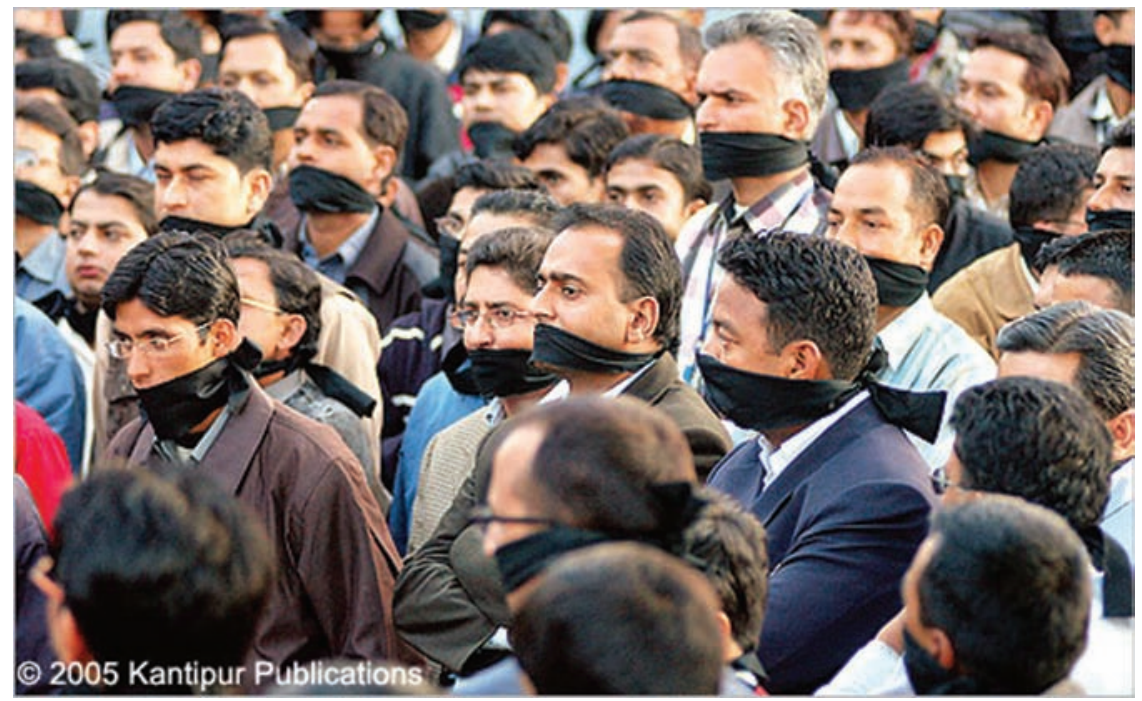

Figure 4. Silent protest against government takeover of media, October 2005. Photo courtesy of Kantipur Publications.

We can think of many other protests around the world that have captivated their audiences through the public performance of silence: the 1917 silent parade of eight to ten thousand African Americans on Fifth Avenue to protest a lynching; the Black Lives Matter silent protests that spread across the United States nearly a hundred years later; the "standing man" protest in Gezi Park in Turkey that spread to cities around the world; the silent vigils of Women in Black that Athena Athanasiou $(2017,225)$ argues reshaped "vocal registers that implicitly condition the configuration of the political." While each instance of silence has its own history, context, and specific intentions, in all these cases silence has a powerful effect in emphasizing social solidarity, solemnity, and violence. Silence also draws attention to a break in communication between authorities and citizens, or a problem with the concept of the public or of politics itself. In these demonstra- 
tions of palpable and visible silence, people dramatize the problems of voicing without uttering a word - a kind of ironic commentary on censorship in which their performance is the inverse of what they seek and desire.

The use of silence aims to inspire talk, and this talk also forms part of the effectiveness of deliberate silence in cultivating political subjects. This "biopolitics of silence," as Ana María Ochoa Gautier (2015, 186) describes it, involves a "dialectic between recognition and negation." On the one hand, the ability of modern subjects to engage in silent concentration leads to rational understanding, while on the other hand, to engage in a "silencing of irrational or noisy forms of listening" (Ochoa Gautier 2015, 186) simultaneously elevates some political subjects and denigrates others as not yet political. In the case of Ashmina's performance, pairing silence with broadcast sounds of crying became a means of reflective engagement with the contemporary political context that tapped into people's affective experience of politics.

When performed by a large group in public, silence often emphasizes death and respectful mourning (Schwartz 2011, 617). Marié Abe $(2016,247)$ convinc-

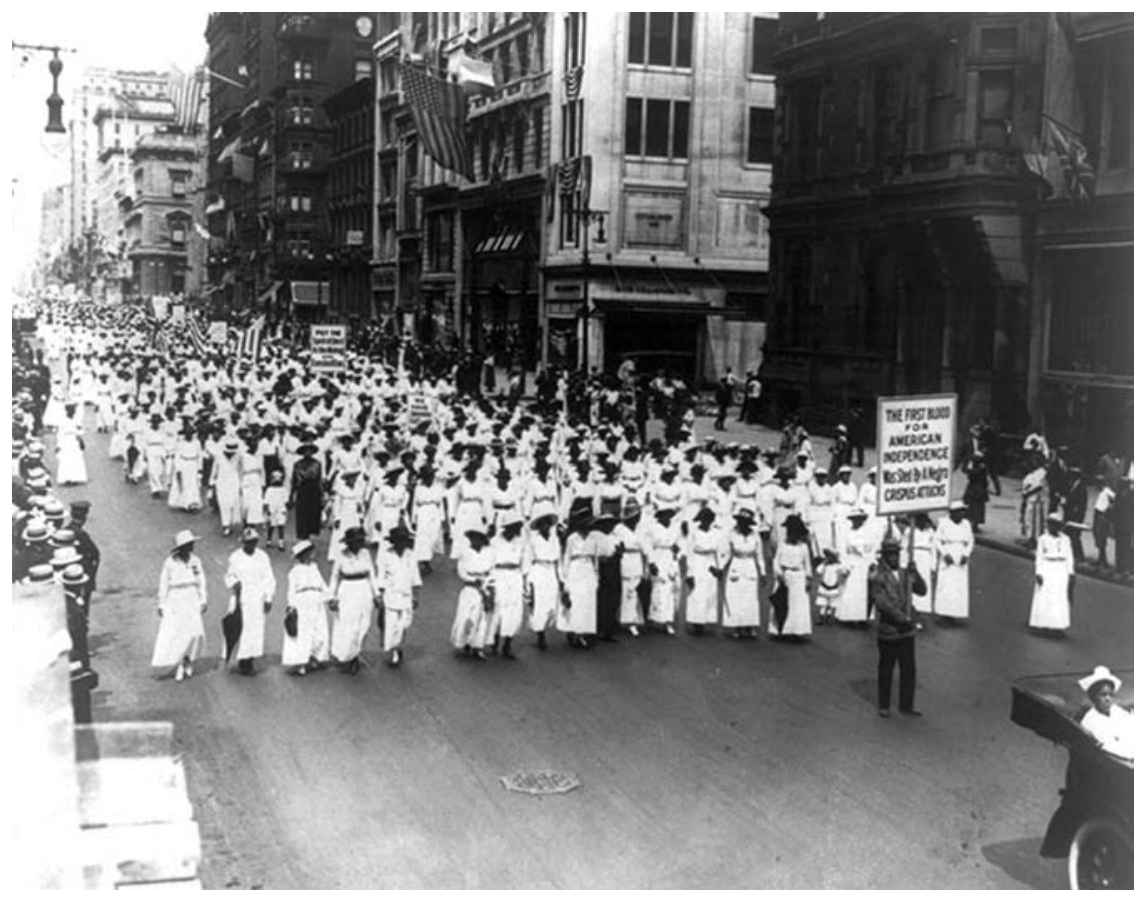

Figure 5. Silent protest against police mistreatment by African Americans in New York City, 1917. Photo by Underwood and Underwood. 


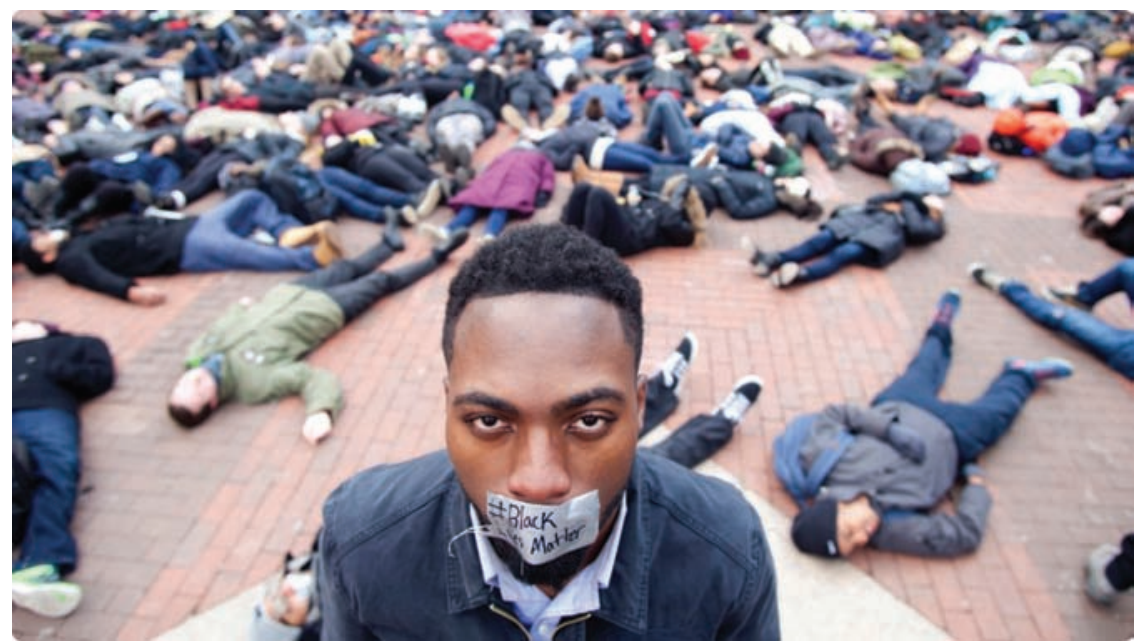

Figure 6. Ashmina's use of voicelessness, coupled with the staging of fallen bodies on the ground, draws on a global repertoire of protest iconography evident in this image of a Black Lives Matter silent protest. Photo by Patrick Record.

ingly shows that, in the aftermath of the 2011 earthquake in Japan, silence was not a sonic performance of oppression or the alter ego of voicing, but became a "performance of national mourning and social embeddedness." This connection was made literal in Ashmina's happening as performers fell to the ground to feign death while their partners traced their bodies in chalk, mimicking global police imagery of death at the scene of a crime.

Athanasiou's $(2005,46)$ analysis of the Women in Black silent vigils to protest Israeli occupation draws attention to "the historical unspeakability and silenced memory of collective traumatic encounters with death that demand our witness when nothing is left to be said.” These silent vigils are sometimes interrupted by women's wails of grief and even occasional screams. Moving between silence and crying, Athanasiou (2005, 47) argues, suggests the way these women "inhabit language in the realms of its most intense and unpronounceable discontinuities (i.e., silence and scream)." Strikingly similar to Ashmina's performance in terms of sounds, this feminist politics performs the inevitable experience of language - "language being at a loss" (Athanasiou 2005, 47) —captivating people through audible expressions that lie at the edge of discourse. In Kathmandu, silent protests like Ashmina's are also forms of āwāj uthāune, of raising voice. 


\section{SECOND MOTIF: BROADCAST WAILING}

Audio 2. Wailing, as part of A Happening. Created by Ashmina Ranjit.

Like the Women in Black vigils, the wordless A Happening was overlaid by sounds of wailing broadcast through several FM radio sets for a full hour. Ashmina compiled her soundtrack using a documentary film about Maoist conflict, The Living of Jogimara (2002), as well as recordings of herself and other actors whom she had hired to cry. "The sound of crying is most effective," Ashmina told me; "it shakes you." Part of what makes crying the most effective sound of protest is its connection to the affective qualities of vocal sound. Although crying, in Nepal as elsewhere, is a gendered and performed genre, it could be seen as pure voice or a voice without language, a voice beyond language and therefore beyond accent. ${ }^{14}$ As Mladen Dolar $(2012,550)$ points out, the sound of an infant's scream "presents speech in its minimal traits, which may later get obscured by articulation." Though words are spoken on the soundtrack, they are not articulated between cries, blurring the sounds of crying with these utterances. The layered crying voices represent many people (but notably, the sobbing comes almost exclusively from women), including babies crying out for their mothers and men trying to console those crying. Voices without clear language, Ashmina felt, expressed the suffering of the nation more powerfully than any words about the war could convey.

The sound of crying is the sound of affect writ large. As a performed genre, crying is associated primarily with women and a necessary part of funerals and weddings, though not usually a public form addressed to strangers. Much as at funerary rituals, most of the crying heard on Ashmina's soundtrack was performed by women whose only enunciation was reference to their children. These mothers' sobs came to represent the nation writ large. Recorded and transmitted over the radio, the sounds of mourning were transposed and remediated first from the familial face-to-face setting to a documentary film and then to a recorded soundtrack broadcast nationally. The anonymity of crying became a means of creating the sense and sensibility of public cohesion, even when there may not have been such a thing. The effect was to dissolve any clear, politicized identities (of class, region, ethnicity, caste, religion, and so on) possibly revealed in a person's accent, word choice, or tone of voice, though one could still hear gender in the cries of 
mothers. It is quite possible that the gendered nature of the sobs rendered the voices more natural, making them appear to transcend political divides to represent the national family or motherland, a term widely embraced throughout South Asia. By placing crying mothers at the center of this piece, Ashmina subverted a dominant Nepali masculine trope of the bir (brave) soldiers of the nation (Onta 1996). After the event, much to Ashmina and her team's surprise, the Maoists claimed the performance to be antigovernment, while government officials claimed that it protested the Maoists.

Several commentators pointed to the "real" quality of the crying. "In order to hit people hard with the message," Pradhan (2004) wrote, "all Kathmandubased FM radios aired real wailing and crying sounds from the war-torn places for an entire hour." The recording of crying and its transmission on the radio proved crucial to creating an audible sense of the real. Because recorded sound is separated from the body and because, unlike the human ear, recording devices do not differentiate between meaningful and meaningless sound, the indexical qualities of a recording often make the voices appear more real, immediate, and pure than symbolic language (see Kittler 1999). Words might be empty or false, but crying seems harder to fake. (However, the fact that the crying soundtrack was produced by a documentary filmmaker and performing actors belies this idea, though no media commentator noted this.)

What kind of subjects do the sounds of crying bring forth? These are not actors who debate rationally about issues of public opinion. These are unnamed, unidentifiable persons whose sounds make them appear to speak as one body, one voice - albeit a clearly gendered voice. The subjects constituted by these sounds may resemble a crowd that stands (at least in twentieth-century social theory) in contrast to the subjects of more self-measured publics (Cody 2011, 41; see also Mazzarella 2010). In his analysis of crowd theories, William Mazzarella (2010, 704) points out that the crowd is central to our image of democracy, but crowds are more often feared in this literature because they lead to a kind of bodily suffusion of affect that "represents a lamentable loss of autonomy." In Ashmina's performance, two different images of crowds collide. Most of those assembled on the street were not crying; a few performers wailed in performed pain, but most performers and their audience remained silent like ghosts, animating a reflective space of assembly. Yet another invisible but audible crowd emerged in the crying voices transmitted through the radio sets. ${ }^{15}$

Crying transduced through radios created what Pierre Schaffer (1966) calls an acoustemic situation where the source of the sound remained unseen (see also 
Kane 2014). A Happening thus emphasized a distance that people in Kathmandu maintained from the source of crying, while at the same time forcing aloof urban residents to engage with the sounds of wartime pain. As Daniel Fisher $(2016,11)$ points out, the voice broadcast via radio inspires "reflexive consideration" and "occasional unease" in the media's "capacity to enable forms of collective selfabstraction . . . and to evoke an alterity, one's 'self' returned as the voice in the machine." Indeed, one of Ashmina's aims was to reach beyond the scene of the street and touch people who were not immediately present for the performance, asking them to recognize themselves or their compatriots in the crying voices.

This national effect was largely created through the soundtrack's transmission on all radio stations. Ashmina had first approached one FM station and found that the manager greeted her with an unexpected openness, having seen her installation Nepal's Situation: 2003, which she had created a year before. In the prior installation, people moved slowly across a burning map of Nepal while the sounds of crying, gunshots, and vague news reports about the dead played through a recording. Ashmina felt that $A$ Happening was a continuation of this project, and the soundtrack largely came from the earlier performance. The station manager agreed to broadcast the soundtrack and, inspired by this, the artist approached another station. Eventually, all fifty-some FM stations agreed to broadcast the soundtrack from 5 to 6 p.m. Many of these Kathmandu-based stations had satellite equipment that they then used to broadcast to other outlets far beyond the capital. Just days before the actual performance, a friend of Ashmina's, the head of the state-run Radio Nepal, contacted her and somewhat inexplicably asked why they had not also been approached. Transmitted over all FM stations and Radio Nepal, the sounds of crying were now to become a broadcast of truly national scope. The process of gaining this approval, Ashmina told me, proved as integral to the piece as the actual performance.

The simultaneous broadcast of the soundtrack on all stations echoed media coverage of the national tragedy of the Narayanhiti palace massacre, when King Birendra and his entire immediate family were murdered. Much as with Ashmina's happening, the media were united in the representation of grief and mourning, though, of course, the events' relation to the state were quite different. After the royal massacre, Radio Nepal, all FM radio stations, and Nepal Television, consistent with Hindu practice, played Hindu mourning music for at least fourteen hours (Hutt 2006; Lakier 2009). All media transformed overnight into sites of Hindu national mourning, where truths about what happened at the palace were 
obscured (or, perhaps, illuminated) in the sound of dirges and televised images of the Pashupatinath temple.

Three years later, Ashmina's performance reinvoked the power of mass media to offer transparent access to truths — political and emotional — for a listening public. And it created a different politics of doubt — not the distrust of the media or the government that Genevieve Lakier (2009) discusses after the royal massacre, but doubt and confusion about what kind of tragedy might have occurred. Some stations, like Radio Nepal, interspersed the sounds of crying with their regularly scheduled programs; many also included an announcement that the broadcast was part of a performance occurring in Kathmandu. When it was broadcast on the street, a few people tried to drown out the sound by turning on other music. Even so, those hearing the sounds of crying assumed something tragic had happened that they did not yet know about, something, like the palace massacre, that was too tragic to report with words. Managers at FM radio stations told Ashmina that the phones had been ringing constantly, with listeners asking what had happened. Several stations just took their phones off the hook, possibly creating more confusion and fear. There were, in many ways, two different happenings: one on the street addressed to a Kathmandu audience, which included students, residents, and migrants from other parts of Nepal; and one that addressed an unseen and unseeing audience through the radio and sound alone. The broadcast transmission of the sounds of crying created a secular, national, and - despite (or perhaps because of) the gendered performance of crying - more human national subject. It sounded, as some observers noted, as though "Nepal is crying."

\section{THIRD MOTIF: HONKING NOISE}

The protests at Baluwatar were similarly deeply intertwined with media. Occupy Baluwatar or Baluwatar Satyagraha (as it was later called by some who wanted to dissociate it from the Western Occupy movements) was initially inspired by reports of a local rape, when a Nepali woman, pseudonymously known as Sita Rai, returned from working in the Persian Gulf in late November 2012, traveling on a fake passport. ${ }^{16}$ To avoid prosecution, a Nepali immigration officer demanded that she pay a bribe of 218,000 rupees - nearly all the money she had earned abroad. Sita Rai was then escorted to a bus park by a policeman from the airport, who repeatedly raped her in a nearby lodge. Sita Rai’s brother began to seek help from women's organizations and the media in mid-December, and the first article about the robbery and rape appeared in the Kathmandu Post on December 28, 2012. ${ }^{17}$ Notably, this article was published after the infamous gang rape of Jyoti 
Singh on a public bus and subsequent anti-rape protests in Delhi had captured global attention. Like many other global movements, the Baluwatar protest campaign began on Facebook and Twitter as enraged activists saw little government response. ${ }^{18}$ They created a petition for the prime minister, first posted on Facebook, and then on other social media they agreed to meet close to his residence for others to sign the petition. They continued to meet near the prime minister's residence every morning from 9 to 11 a.m. beginning on December 28, 2012, for a continuous 107 days in hopes of delivering the petition in person.

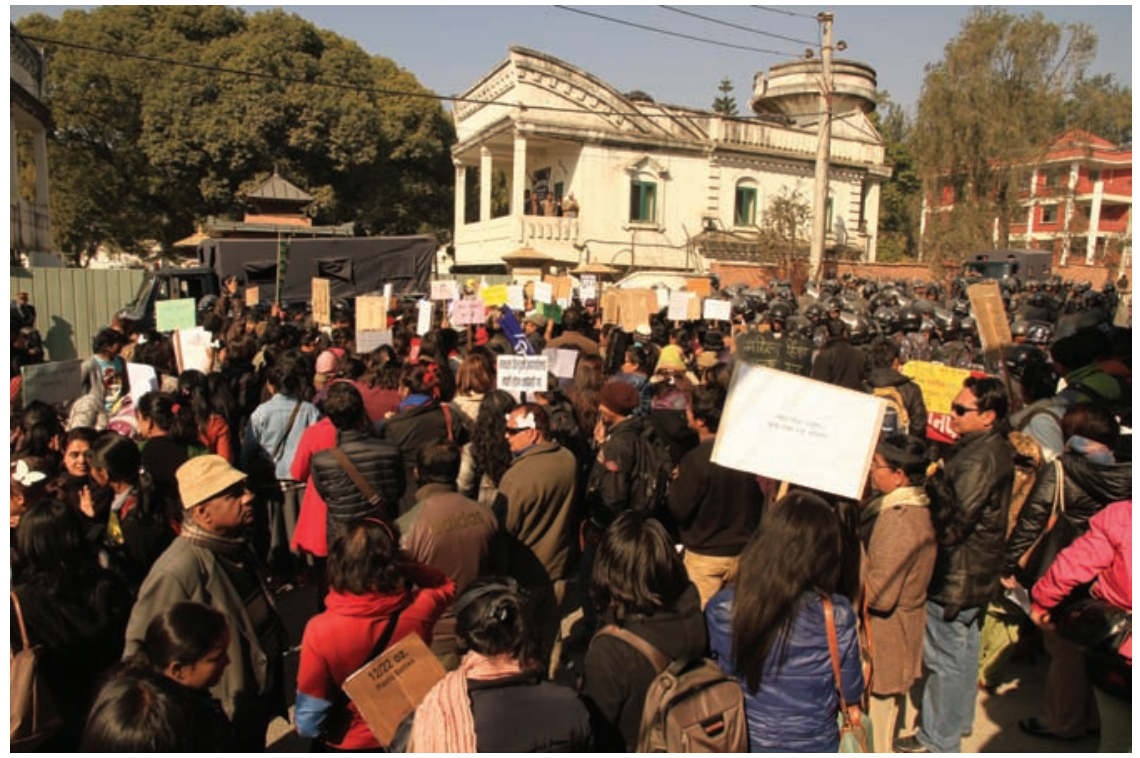

Figure 7. Occupy Baluwatar, in front of Nepal Rastra Bank. Photo courtesy of Prajwal Tulachan.

A year after the Occupy Baluwatar protests, which I had witnessed digitally from my home in New York, I went to Nepal to talk with several of the activists involved. Ujwal Thapa, one member who was active on social media, met me in the office of his then newly founded youth political party, Bibeeksheel Nepali (Rational Nepali). Ujwal claimed that their tactics of protest in Occupy Baluwatar were "new," in part to keep the attention of the media. "The media loves different things," Ujwal told me. "The media would not continuously show this if it were just people shouting. . . . We used to have impulsive dances . . . a flash-mob concert. . . . You spice it up that way." Ujwal posted a YouTube video of the protest from the first day until the forty-fifth, and regularly consulted the Internet 
for ideas on how to protest, including Gene Sharp's well-known "198 Methods of Nonviolent Action.” A graduate of Bennington College, Ujwal's cosmopolitan persona is reflected in his avid Internet use; he describes himself as a former "computer game addict."

In contrast to the highly cultivated and minimalist soundscape of $A$ Happening, activists at Baluwatar sought to disrupt the status quo by transforming all kinds of noise into signs of protest. Each day the activists turned the side of the road in front of the prime minister's residence into a stage where, in addition to the usual repertoire of political slogans and banners, numerous performances took place. These ranged from poetry slams to performance art (by Ashmina and some of her friends) and silent protests; from banging plates and chimes, blowing whistles, and asking people to honk in support to staging a so-called Superman rally that mocked contemporary politicians by walking in procession in front of the police academy while wailing.

Audio 3. Flash mob wailing in front of Kathmandu police headquarters. Created by Prajwal Tulachan.

Noise is popularly thought of as prepolitical and nonreflexive, an unintentional effect of urban life rather than a calculated disruption - as sound "that must be listened through," writes Hillel Schwartz (2011, 37): "Hard candies slowly unwrapped at harpsichord concerts, a chainsaw upriver of a wilderness camp." The incidental noise of infrastructure or modern urban life, Brian Larkin (2008) has argued, is the unstable, accidental interference and breakdowns that are a function of mediation itself - the involuntary loss of signal - that is particularly clear in technological mediation. But noise is also associated with the intentional unruliness of a crowd that threatens to spin out of control, to go against law and order, and to challenge some of the foundations of liberal democracy. As David Novak (2015, 130) notes, noise is an accusation by those in dominant positions against seemingly unruly marginal groups. "'Bringing the noise' is not accidental," writes Novak (2015, 131), "but an expressive practice and a deliberate act of subversion." 19 Such is the case with Japanese musical groups performing in antinuclear protests that seek to break apart and challenge state-sanctioned silence and nuclear policy (Novak 2013; Manabe 2015; Abe 2016). ${ }^{20}$ Such was also the case among the Quebec manifs casseroles in 2012, which brought together a wide 
range of people from different classes, languages, races, and genders to participate in the infectious banging of pots and pans to protest a law that banned large gatherings (Sterne and Davis 2012). Noise always threatens to become polluting, to be read by authorities or those on the street as merely chaotic disturbances that make no sense and need to be brought under regulation. ${ }^{21}$

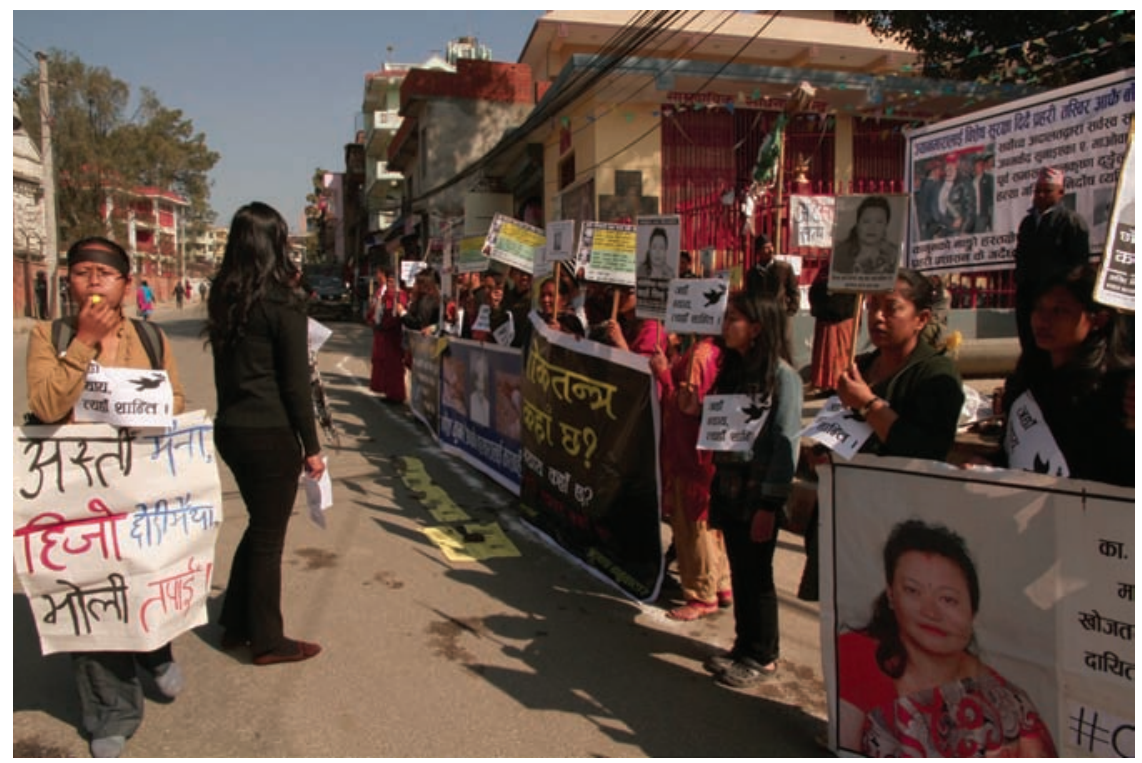

Figure 8. Occupy Baluwatar noise. Photo courtesy of Prajwal Tulachan.

Occupy Baluwatar transformed everyday activities like driving to work from the audible traces of moving traffic into a noisy sounding of support for their movement. The prime minister's residence is located in a wealthy area of Kathmandu, a neighborhood populated by expats, diplomats, Nepali businesspeople, and government officials, all of whom have cars. The level of traffic makes this thoroughfare particularly congested during rush hour. The activists on several days held up signs asking people to "honk in support" (horn bajāyera samarthan garnu hos!). "Don't forget to honk your horns to show your support in ending violence against women" read one caption to a YouTube video. Many activists also blew whistles, echoing the sound of traffic police.

Audio 4. Everyday traffic sounds, Kathmandu. Created by Laura Kunreuther. 
At the time, horn-blowing formed part of the etiquette of driving in Nepal. ${ }^{22}$ Having spent much time traveling the streets of Kathmandu on a bicycle or motor scooter during the late 1990s and early 2000s, I learned the basic rules of moving through traffic. Rule number one is to never look behind you or in the rear-view mirror, because what happens in front of you is always changing and needs to be the focus if one is to maneuver successfully on the city's streets. Rule number two, related to number one, is to honk or beep or ring your bell continuously in short staccato bursts as you approach a vehicle in front of you, particularly when passing, so that others know you are there. Along with honking, the streets used to ring with the sounds of police whistles, as the police attempted to direct traffic in particularly congested areas.

Audio 5. Honking, whistling, and chimes, as part of Occupy Baluwatar. Created by Prajwal Tulachan.

The honks and whistles of protest are, in comparison, much longer in duration and volume, signifying a difference from driving as usual. In asking people to honk while driving, Occupy Baluwatar positioned itself firmly against popular protest movements in Nepal (and elsewhere in South Asia) that seek to take over public space by burning tires in the street, obstructing the roads, calling for transportation strikes to prevent free movement, and thereby presenting a real problem for liberal notions of democratic practice (Lakier 2007, 253). Occupy Baluwatar protesters demonstrated that they were specifically not obstructing traffic by making strategic use of the noisy sounds of still-moving vehicles to signify support for their campaign. "We only knew about traditional ways of protest in Nepal. Strikes . . . close down the streets, close down the city, beat up the police," Ujwal told me, reflecting on prior activist strategies. "We were very tired of this. Since we were such a small group, we knew that this is not the way that like-minded, civil Nepalese would actually do it. . . . We only stopped the road once and that was because the police had blocked the road." Noise was not, then, a tactic of subaltern obstruction. Noise was rather a strategy aimed to support what Ujwal calls “civil” democratic principles. This was clearly an important message, because toward the end of the 107 days, the police arrested some protesters for moving into the road and obstructing traffic, a charge that protesters deny. Honking became one of several ways activists transformed seemingly meaningless noise into the sounds of democratic protest. 


\section{FOURTH MOTIF: BANGING PLATES}

In a YouTube video for the thirtieth day of the Baluwatar protests, protesters invited others to join: "Today, sitting down in silence with pots and pans, hungry for justice. Do join tomorrow." The video, while hardly silent, shows many protesters with black cloths tied around their mouths, shaking small tin plates with coins inside or lightly tapping the plates with spoons in rhythmic unison.

Audio 6. Tapping plates, as part of Occupy Baluwatar. Created by Prajwal Tulachan.

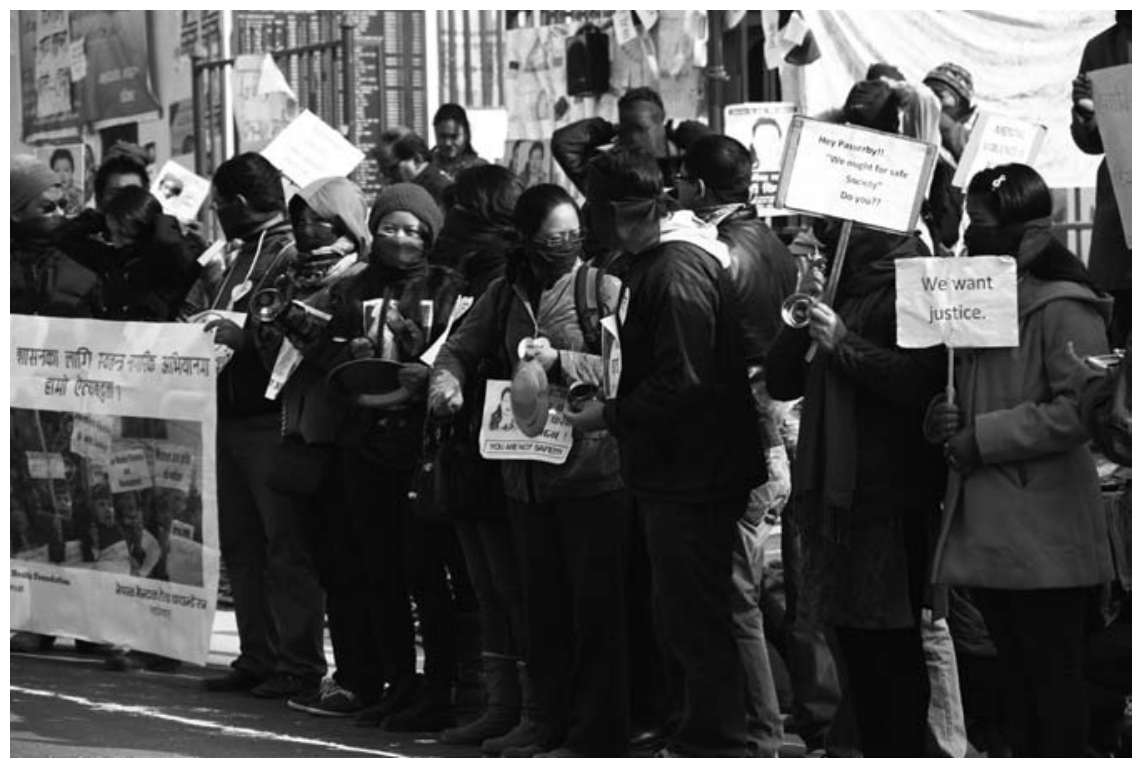

Figure 9. Participants in Occupy Baluwatar tapping plates during an otherwise silent protest. Photo courtesy of Prajwal Tulachan.

The use of pots, pans, and metal plates to create the noise of protest is a global phenomenon, used in Argentina (where the practice is said to have originated) and other parts of South America, Quebec, and Turkey. Jonathan Sterne and Natalie Zemon Davis (2012) link the percussive banging on pots and pans in the 2012 Quebec protests to the charivari protests in early modern and modern France, when noisy demonstrations "call[ed] attention to a breach of community standards in the village or neighborhood." Here protesters turn everyday domestic items into the weapons of protest, effectively bringing the home into the public. Besides, drumming out beats together on pots and pans is also just plain fun. 
This was not a new tactic of protest in Nepal, either. During the People's Movement of 2006, when the king had declared a curfew that banned people from the streets, many went to the top of their roofs and loudly banged metal plates with spoons, creating a deafening echo across the valley. Participants told me that it was unlike any other protest. As one of my close friends explained, the repetitive rhythms expressed and generated a "sea of emotions" for political change and a "feeling of full control" that was not possible during the heavily censored and policed concurrent daytime protests. Some explained this act as a means of humiliating King Gyanendra, as if to say: "You say you will not listen to us, but we will make sure you literally hear the sound of our discontent from our homes." As in the Gezi Park protests in Turkey, the call to bang on pots and metal plates came from all around the city sometime after dark, when people called for a complete blackout of lights across the city. In 2015, a similar protest took place when Nepalis loudly banged plates with spoons during daytime hours to demand a legal change that would give rights to mothers, like the rights vested in fathers, to pass citizenship on directly to their children. The infectious noise animated participation (Gürsel 2013). Like the sounds of recorded cries, banging plates transmits little political content other than an overall affective tone: an orchestrated demonstration of anger and discontent, rather than the sorrow and pain of cries. The content of protest remains obscured in the din of banging that echoes across the city, signifying through noise a breakdown in communication between ruler and ruled.

There were additional meanings attributed to the plate tapping at Baluwatar. Plates and spoons were signs of hunger, and combined with the constant call-andresponse chanting of "What do [we] need? [We] need justice!" during the protest, the sound of plate tapping spoke to the protesters' "hunger for justice," as the YouTube caption stated and as one prominent activist repeated to me. Several participants suggested the appropriateness of banging plates and pots in a public campaign against violence against women, given the domestic labor women perform in the home and the usual silence surrounding violence against women. The same noise of banging plates, then, can acquire different meanings that must be understood ethnographically for both their global and local resonances.

\section{CONCLUSION}

The four sonic motifs I have considered here are all examples of $\bar{a} w \bar{a} j$ and $\bar{a}$ wāj uthāune, which cannot be fully understood within the classic frames of the voice of publics or the unruly noise of crowds. Crowds, and the noise they 
generate, typically address the embodied and affective dimensions of political subjectivity that cannot be clearly subsumed in a single political opinion. In contrast to the voice of the people, the roar of the crowd suggests an apolitical (or even antipolitical) dimension of those who have not yet found their voice to be represented. Yet, as I have argued here, $\bar{a} w \bar{a} j$ is orchestrated sound that is clearly embodied, affective, and simultaneously constitutive of political subjects.

What does it mean to write about the sounds of participatory democracy at this divisive political moment around the world? Democratic soundscapes draw our attention toward the affective and embodied nature of political performance, aspects of democracy that are often disavowed or aggressively disparaged in mainstream discussions of a rational public sphere and the political ethics of communication. Certainly, there are many critical approaches to understanding the relationship between emotional and aesthetic expression within mass politics and modes of authoritarian power. This essay suggests novel ways of understanding such relationships by tuning our attention to sound. Walter Benjamin $(1968,241)$ famously argued that "fascism sees its salvation in giving these masses not their right, but instead a chance to express themselves. Fascism seeks to give them an expression while preserving property.”

Today's critic must explore the inseparable links between the rational and the affective, the ideational and the material by asking the question: what does democracy sound like? The sounds inherent in participatory democracy depend not on a single speaker but on collectivities — often assembled en masse - to make any message heard within the polyphony of perspectives that can constitute ongoing, collaborative deliberation. The South Asian concept of $\bar{a} w a \bar{j} j$ expands our notions of the voice from expression of consciousness or political desire toward the edges of language. Cries, silence, honking, the din of banging plates - these bring forth a political subjectivity based on both intention and affect, a rhetoric of noise and silence, in a transmission of sound that is at once mass-mediated and acutely embodied.

\begin{abstract}
This article asks a deceptively simple question: what does democracy sound like? Democracy is commonly associated with various forms of voicing - political speeches, shouting protesters, filibusters in the halls Congress, or heated debates in teashops, salons, and newspapers around the world. Voice thus often functions as a metaphor for political participation and representation. Political metaphors of voice are usually disembodied, and are rarely invoked in reference to the other forms for political
\end{abstract}


utterance, sound, or even noise that make up the many practices of participatory democracy. In such contexts, the notion of voice depends not on a single speaker but on a mass collectivity to make any message heard. The South Asian term āwāj refers explicitly to both the sonic and metaphorical meanings of voice, which this article uses to provincialize more commonly used global metaphors of voice. I consider what democracy sounds like by following the pathways of āwāj through two examples of participatory democracy on the streets of Kathmandu: a performance art piece and a political protest called Occupy Baluwatar. Āwāj and the sonic motifs I explore in these performances offer a conceptual rubric for breaking open the discourse of voice used in global human-rights organizations, humanitarian discourse, and liberal understandings of the public sphere, bringing forward a political subjectivity based on both intention and affect in a transmission of sound that is at once mass-mediated and acutely embodied. [voice; democracy; sound; noise; affect; protests; political subjectivity]

\section{NOTES}

Acknowledgments I thank, first and foremost, my generous friends in Nepal without whom this article would not exist, particularly Ashmina Ranjit, Prajwal Tulachan, Pranika Koyu, Ujwal Thapa, and Hikmat Khadka. This essay benefited at various stages from the comments of numerous colleagues and friends. I thank participants in the University of Pennsylvania's Anthropology Colloquium Series, who commented on a very early version, particularly Asif Agha, Lisa Mitchell, Deborah Thomas, Greg Urban, and Amanda Weidman; the members of Bard College's Sound Cluster (Alex Benson, Matthew Deady, Maria Sonevetsky, Olga Touloumi, Danielle Riou); participants in the "Making Noise" panel at the 2014 American Ethnological Society Spring Meeting; participants in the "Anthropology of Sound Forum" at the 2016 Society for Ethnomusicology meetings, particularly Alex Dent, Lila Gray, Danny Fisher, and Dave Novak; Bob Bilecki for his suggestions on the sounds; Dhana Hamal, Danielle Hanley, Daniel Karpowitz, Penelope Papailias, Jonah Rubin, Sara Shneiderman, and Karen Strassler for their individual readings at various stages of writing. I also thank the Avery Review, where I published a portion of the ethnographic material about Ashmina's performance to make an early argument about democratic soundscapes. Finally, thank you to the two anonymous reviewers and to the editorial team at Cultural Anthropology for their insightful suggestions, especially Cymene Howe and the wonderfully efficient managing editor, Marcel LaFlamme. Any remaining mistakes remain my own.

1. See Keane 1999; Weidman 2006, 2014; Harkness 2013; Kunreuther 2014; Ochoa Gautier 2014; Fisher 2016 for similar critiques of disembodied voices.

2. These letters produce a form of self-presentation, which I have called voiced writing (Kunreuther 2014). This form bears a resemblance to Ana María Ochoa Gautier’s (2014, 171) argument about the immunized voice, a voice that emerges through "the rules of writing."

3. The association between voice, speech, and sound is also present in the Nepali term halla , a term that, depending on context, refers to rumors (uncontrolled, widely circulating talk without a specific author) or intentional or inevitable noise (unwanted sounds that makes other sounds inaudible). Like $\bar{a} w a \bar{j}$, the term halla equally forms part of political discourse and practice (see Lakier 2014, 211-53; Lecomte-Tilouine 2017). While hallā sometimes acquires negative connotations as meaningless noise or unconfirmed tales without a source, $\bar{a} w \bar{a} j$ is uniformly understood as more formal and coming from an identifiable source. It refers to an individual or collective group's authentic expression and its particular truth. 
4. The piece's title reveals Ashmina's connection to early 1960s performance artists in the United States and Europe, who frequently called their performances "happenings" (Thapa 2011, 19). Ashmina received a master of fine arts at Columbia University, where she studied under the performance artist Coco Fusco.

5. Gender was a crucial element in both of these events, and while I touch on this subject as it relates to sound, a fuller exploration of feminist aspects must be explored elsewhere; see Koyu and Pokharel 2014 and Pudasaini 2016.

6. Manoukian cites the Persian word seda (sound, noise, voice) in his discussion of Iranian postelection videos. The Persian term avaaz, to which āwāj is connected, typically refers to chanting and singing without political connotations (Setrag Manoukian, pers. comm.).

7. Rather than treat inarticulate sound in opposition to human uses of the voice, I view such strategic use of nondiscursive sound as a continuum alongside articulate language; see Ochoa Gautier 2014, 169.

8. The overlapping cacophony of distinct yet somehow unified sounds is what marks these as democratic soundscapes, as opposed to another political form. Fascism or totalitarian soundscapes, for example, might center on a microphone with a single voice (e.g., Strassler 2009).

9. Just as with Stefan Helmreich's (2016) exploration of sound in his article "Gravity's Reverb," sound forms an integral aspect of this analysis. I have incorporated sound into the text as a performative exercise parallel to the artists' and activists' performances I describe. New digital technologies enable us to do "anthropology in sound" (Feld and Brenneis 2004) in ways that creatively ask us to think beyond the written word.

10. The Kathmandu Valley is made up of three adjacent cities: Kathmandu, Patan, and Bhaktapur. Kathmandu and Patan are only separated by a bridge across the Bagmati River, and many people move between the two cities daily, often several times a day. Bhaktapur is nine miles away from Kathmandu. In this passage, I refer specifically to the sounds in Kathmandu and Patan.

11. A bahal is a typical Newar urban housing structure, in which a group of homes are built around an enclosed residential courtyard that all of the families use. Newars are a dominant ethnic group in the Kathmandu Valley.

12. See Lakier 2014 for the history and meaning of bandas and other such protests in Nepal.

13. Khagendra Sangroula (2008) refers to these protests metaphorically as the "Festival of the Black Band.”

14. See Feld 1982, Seremetakis 1991, and Wilce 1998 for ethnographies that discuss the performative and often gendered aspects of lamentations and crying.

15. Several days after her performance, though, one political group organized a procession in which all the youth involved walked in procession wailing, after which some participants apparently asked, "where is Ashmina?"

16. See Koyu and Pokharel 2014, Saldaña 2014, and Pudasaini 2016 for a full summary of the incident and the ensuing movement. While initially inspired by the rape case discussed above, there were several other instances of violence against women that became linked to Occupy Baluwatar.

17. Saldaña $(2014,39)$ cites a woman journalist from the Kathmandu Post who felt that the media was not adequately covering the issue because "no one wanted to cover women's issues." Surabhi Pudasaini (2016) notes significant differences in the English- and Nepalilanguage press.

18. The government officials were merely suspended from their duties, and the government offered the family less than half of the money stolen from Sita Rai at the airport.

19. Political movements explicitly reference the use of noise to indicate their alignment with subaltern or nondominant groups, such as Russia's well-known Pussy Riot. Amnesty International, while hardly subaltern, devised a human-rights campaign called "Bring on the Noise."

20. Novak's (2013) work on musicians performing at antinuclear protests following the 3/ 11 disaster in Japan shows precisely this tension. See also Emily Thompson's (2002) 
The Soundscape of Modernity, in which she traces early noise-abatement policies in New York in the 1920s.

21. Crowds on the street and noise are typically juxtaposed with a silent and rational reading public, and both are disavowed in discussions about political voice. As several scholars have suggested, the analysis of crowds and mass affect helps us reconsider political subjectivity "beyond liberal frameworks" (Cody 2015, 63) of the public sphere; see also Manoukian 2010; Mazzarella 2010, 2015; Butler 2015).

22. Urban soundscapes are always historical, responding to changes in population, work, technology, and law. This urban soundscape radically changed once a new regulation was put in place in the spring of 2017 that forbids honking. Signs were hung around Kathmandu announcing the new rule, and it was enforced by traffic police through significant fines. To many people's surprise, the sounds of continuous honking almost completely disappeared from Kathmandu streets within a few days of the regulation. In this changed context, no longer can activists like those at Baluwatar depend upon honking as a strategy of support.

\section{REFERENCES}

Abe, Marié

2016 "Sounding against Nuclear Power in Post-3.11 Japan: Resonances of Silence and Chindon-ya." Journal of Ethnomusicology 60, no. 2: 233-62. https://doi.org/

Athanasiou, Athena 10.5406/ethnomusicology.60.2.0233.

2005 "Reflections on the Politics of Mourning: Feminist Ethics and Politics in the Age of Empire.” Historein 5: 40-57. https://doi.org/10.12681/historein.72.

2017 Agonistic Mourning: Political Dissidence and the Women in Black. Edinburgh, UK: Edinburgh University Press.

Avaaz

n.d. "About Us." https://avaaz.org/page/en/about.

Bate, Bernard

2009 Tamil Oratory and the Dravidian Aesthetic: Democratic Practice in South India. New York: Columbia University Press.

Benjamin, Walter

1968 "The Work of Art in the Age of Mechanical Reproduction." In Illuminations, edited by Hannah Arendt and translated by Harry Zohn, 217-51. New York: Schocken. Originally published in 1936.

Bonilla, Yarimar and Jonathan Rosa

2015 "\#Ferguson: Digital Protest, Hashtag Politics, and the Racial Politics of Social Media in the United States." American Ethnologist 42, no. 1: 4-17. https:// doi.org/10.1111/amet.12112.

Burghart, Richard

1996 "The Conditions of Listening: The Everyday Experience of Politics in Nepal." In The Conditions of Listening: Essays on Religion, History, and Politics in South Asia, edited by C. J. Fuller and Jonathan Spencer, 300-318. New York: Oxford University Press.

Butler, Judith

2015 Notes Toward the Performative Theory of Assembly. Cambridge, Mass.: Harvard University Press.

Chakrabarty, Dipesh

2000 Provincializing Europe: Postcolonial Thought and Historical Difference. Princeton, N.J.: Princeton University Press.

Chatterjee, Partha

2006 Politics of the Governed: Reflections on Politics in Most of the World. New York: Columbia University Press. 
Cody, Francis

2011 "Publics and Politics." Annual Review of Anthropology 40: 37-52. https://doi.org/ 10.1146/annurev-anthro-081309-145626.

2015 "Populist Publics: Print Capitalism and Crowd Violence beyond Liberal Frameworks." Comparative Studies of South Asia, Africa, and the Middle East 35, no. 1: 50-65. https://doi.org/10.1215/1089201X-2876092.

Dolar, Mladen

2012 “The Linguistics of the Voice." In The Sound Studies Reader, edited by Jonathan Sterne, 539-54. New York: Routledge.

Feld, Steven

1982 Sound and Sentiment: Birds, Weeping, Poetics, and Song in Kaluli Expression. Philadelphia: University of Pennsylvania Press.

Feld, Steven, and Donald Brenneis

2004 “Doing Anthropology in Sound.” American Ethnologist 31, no. 4: 461-74. https:// doi.org/10.1525/ae.2004.31.4.461.

Fisher, Daniel

2016 The Voice and Its Doubles: Media and Music in Northern Australia. Durham, N.C.: Duke University Press.

García Molina, Andrés, and Julien Cossette

2016 "Election's Reverb: An Interview with Stefan Helmreich." Dialogues, Cultural Anthropology website, December 16. https://culanth.org/fieldsights/1011-

Gray, Lila Ellen election-s-reverb-an-interview-with-stefan-helmreich.

2013 Fado Resounding: Affective Politics and Urban Life. Durham, N.C.: Duke University Press.

Gürsel, Zeynep Devrim

2013 “\#potsandpans: Rethinking Social Media in Istanbul during Occupy Gezi." Anthropology Now 5, no. 3: 67-73.

Habermas, Jürgen

1989 The Structural Transformation of the Public Sphere. Translated by Thomas Burger with the assistance of Frederick Lawrence. Cambridge, Mass.: MIT Press. Originally published in 1962 .

Harkness, Nicholas

2013 Songs of Seoul: An Ethnography of Voice and Voicing in Christian South Korea. Berkeley: University of California Press.

Helmreich, Stefan

2016 “Gravity's Reverb: Listening to Space-Time, or Articulating the Sounds of Gravitational-Wave Detection.” Cultural Anthropology 31, no. 4: 464-92. https://doi.org/10.14506/ca31.4.02.

Hindman, Heather

2014 "Postpolitical in the Postconflict: DIY Capitalism, Anarcho-Neoliberalism, and Nepal's Ungovernable Mountains. In "The Politics of 'Postconflict': On the Ground in South Asia," Hot Spots series edited by Sara Shneiderman and Amanda Snellinger, Cultural Anthropology website, March 24. https://culanth.org/ fieldsights / 507-post-political-in-the-post-conflict-diy-capitalism-anarcho-

Hutt, Michael neoliberalism-and-nepal-s-ungovernable-mountains.

2006 "Things that Should Not Be Said: Censorship and Self-Censorship in the Nepali Press Media, 2001-02.” Journal of Asian Studies 65, no. 2: 361-92. https://

Juris, Jeffrey doi.org/10.1017/S0021911806000696.

2012 "Reflections on \#Occupy Everywhere: Social Media, Public Space, and Emerging Logics of Aggregation." American Ethnologist 39, no. 2: 259-79. https://doi.org/ 10.1111/j.1548-1425.2012.01362.x. 
Juris, Jeffrey, and Maple Razsa, eds.

2012 “Occupy, Anthropology, and the 2011 Global Uprisings." Hot Spots series, Cultural Anthropology website, July 27. https://culanth.org/fieldsights/63occupy-anthropology-and-the-2011-global-uprisings.

Kane, Brian

2014 Sound Unseen: Acousmatic Sound in Theory and Practice. New York: Oxford University Press.

Keane, Webb

1999 “Voice." Journal of Linguistic Anthropology 9, nos. 1-2: 271-73. https://doi.org/ 10.1525/jlin.1999.9.1-2.271.

Kelp-Stebbins, Katherine, and Allison M. Schifani

2015 "The Medium is the Masses: Embodied Amplification, Urban Occupation." Media Fields Journal, no. 9. http://www.mediafieldsjournal.org/the-medium-is-themasses / 2015/8/21/the-medium-is-the-masses-embodied-amplification-urbanoccupa.html.

King, Homay

2012 “Antiphon: Notes on the People's Microphone." Journal of Popular Music 24, no. 2: 238-46. https://doi.org/10.1111/j.1533-1598.2012.01327.x.

Kittler, Friedrich A.

1999 Gramophone, Film, Typewriter. Translated by Geoffrey Winthrop-Young and Michael Wutz. Palo Alto, Calif.: Stanford University Press. Originally published in 1986.

Koyu, Pranika, and Astha Sharma Pokharel

2014 “Occupy Baluwatar: A Reflection." Studies in Nepali History and Society 19, no. 2: 347-72. http://www.martinchautari.org.np/index.php/studies-in-nepalihistory-and-society-sinhas/52-publications/journals1/sinhas/626-sinhasvolume-19-number-2.

Kunreuther, Laura

2014 Voicing Subjects: Public Intimacy and Mediation in Kathmandu. Berkeley: University of California Press.

2017 “Democratic Soundscapes.” Avery Review, no. 21. http://averyreview.com/ issues $/ 21$ /democratic-soundscapes.

Lakier, Genevieve

2007 "Illiberal Democracy and the Problem of Law: Street Protests and Democratization in Multiparty Nepal.” In Contentious Politics and Democratization in Nepal, edited by Mahendra Lawoti, 251-72. Los Angeles: SAGE.

2009 “After the Massacre: Secrecy, Disbelief, and the Public Sphere in Nepal." In Censorship in South Asia: Cultural Regulation from Sedition to Seduction, edited by Raminder Kaur and William Mazzarella, 206-234. Bloomington: Indiana University Press.

2014 "The Spectacle of Power: Coercive Protest and the Problem of Democracy in Nepal." PhD dissertation, University of Chicago.

Larkin, Brian

2008 Signal and Noise: Media, Infrastructure, and Urban Culture in Nigeria. Durham, N.C.: Duke University Press.

Lecomte-Tilouine, Marie

2017 “The Royal Palace Massacre, Rumors, and Print Media in Nepal." In Political Change and Public Culture in Post-1990 Nepal, edited by Michael Hutt and Manabe, Noriko Pratyoush Onta, 15-38. New York: Cambridge University Press.

2015 The Revolution Will Not Be Televised: Protest Music after Fukushima. New York: Oxford University Press. 
Manoukian, Setrag

2010 "Where Is This Place? Crowds, Audio-vision, and Poetry in Postelection Iran." Public Culture 22, no. 2: 237-63. https://doi.org/10.1215/08992363-2009027.

Mazzarella, William

2010 “The Myth of the Multitude, or Who's Afraid of the Crowd?" Critical Inquiry 36, no. 4: 697-727. https://doi.org/10.1086/655209.

2015 “Totalitarian Tears: Does the Crowd Really Mean It?” Cultural Anthropology 30, no. 1: 91-112. https://doi.org/10.14506/ca30.1.06.

Mitchell, W. J. T.

2012 “Image, Space, and Revolution: The Arts of Occupation.” Critical Inquiry 39, no. 1: 8-32. https://doi.org/10.1086/668048.

Novak, David

2013 "Performing Antinuclear Movements in Post 3.11 Japan." Paper presented at the Second 3.11 Virtual Conference, March 11-14. https:// fukushimaforum.wordpress.com/online-forum-2/second-3-11-virtualconference-2013/performing-antinuclear-movements-in-post-3-11-japan.

2015 “Noise." In Keywords in Sound, edited by David Novak and Matt Sakakeeny, 12538. Durham, N.C.: Duke University Press.

Ochoa Gautier, Ana María

2014 Aurality: Listening and Knowledge in Nineteenth-Century Colombia. Durham, N.C.: Duke University Press.

2015 “Silence." In Keywords in Sound, edited by David Novak and Matt Sakakeeny, 183-92. Durham, N.C.: Duke University Press.

Onta, Pratyoush

1996 "Creating a Brave Nepali Nation in British India: The Rhetoric of Jati Improvement, Rediscovery of Bhanubhakta, and the Writing of Bir History." Studies in Nepali History and Society 1, no. 1: 37-76. http:// www.martinchautari.org.np/index.php/52-publications/journals1/sinhas/271sinhas-volume-1-number-1.

Pradhan, Saurava

2004 “Ashmina 'Raises Her Voice' against Present Madness.” Kathmandu Post, May 2. Pudasaini, Surabhi

2016 “Reflections on Occupy Balawatar." In A Difficult Transition: The Nepal Papers, edited by Mandira Sharma and Seira Tamang, 256-304. New Delhi: Zubaan.

Saldaña, Elizabeth

2014 "Searching for Justice Online and In the Streets: The Use of Social Media in Movements for Accountability in Nepal and the United States." Senior essay, Yale University.

Sangroula, Khagendra

2008 “Kalopati purba.” In Samjhanaka kuinetaharu, 33-56. Kathmandu, Nepal: Ratna Pustak Bhandar.

Schaffer, Pierre

1966 Traité des objets musicaux: Essais interdisciplines. Paris: Editions du Seuil.

Schwartz, Hillel

2011 Making Noise: From Babel to the Big Bang and Beyond. New York: Zone Books.

Seremetakis, Nadia

1991 The Last Word: Women, Death, and Divination in Inner Mani. Chicago: University of Chicago Press.

Snellinger, Amanda Amanda

2010 "Transfiguration of the Political: Nepali Student Activism and the Politics of Acculturation.” PhD dissertation, Cornell University. http://hdl.handle.net/ $1813 / 17734$. 
Sonevytsky, Maria

2016 "The Freak Cabaret on the Revolutionary Stage: On the Ambivalent Politics of Femininity, Rurality, and Nationalism in Ukrainian Popular Music." Journal of Popular Music 28, no. 3: 291-314. https://doi.org/10.1111/jpms.12174.

Sterne, Jonathan, and Natalie Zemon Davis

2012 "Quebec's Manifs Casseroles Are a Call for Order." Globe and Mail, May 31. https: / / www.theglobeandmail.com/opinion/quebecs-manifs-casseroles-are-acall-for-order/article4217621.

Stoler, Ann Laura

2007 “Affective States." In A Companion to Anthropology of Politics, edited by David Nugent and Joan Vincent, 4-20. Malden, Mass.: Blackwell.

Strassler, Karen

2009 "The Face of Money: Currency, Crisis, and Remediation in Post-Suharto Indonesia.” Cultural Anthropology 24, no. 1: 68-103. https://doi.org/10.1111/ j.1548-1360.2009.00027.x.

Tausig, Benjamin

2015 “Twitchy Ears: A Document of Protest Sound at a Distance." Sounding Out!, August 24. https://soundstudiesblog.com/2015/08/24/twitchy-ears-aThapa, Archana document-of-protest-sound-at-a-distance.

2011 "Performance Art: Feminine Representations as Cultural Intervention." In IMAP Reader: A Collection of Essays on Art and Theater in Kathmandu, edited by Sanjeev Uprety and Robin Piya, 17-36. Kathmandu: Himal Books.

Thompson, Emily

2002 The Soundscape of Modernity: Architectural Acoustics and the Culture of Listening in America, 1900-1933. Cambridge, Mass.: MIT Press.

Turner, Ralph Lilley

1931 A Comparative and Etymological Dictionary of the Nepali Language. New Delhi: Allied Publishers.

Uprety, Sanjeev

2004 “The Canvass of History." Kathmandu Post, May 7.

Weidman, Amanda

2006 Singing the Classical, Voicing the Modern: The Postcolonial Politics of Music in South India. Durham, N.C.: Duke University Press.

2014 "Voice and Anthropology." Annual Review of Anthropology 43: 37-51. https:// doi.org/10.1146/annurev-anthro-102313-030050.

Wilce, James M.

1998 Eloquence in Trouble: The Poetics and Politics of Complaint in Rural Bangladesh. New York: Oxford University Press. 